\title{
Reaching Out: A University Botanical Garden Builds Long-distance Relationships
}

\author{
Robert D. Byers
}

AdDitIONAL INDEX WORDS. educational programs, Elderhostel, U SDA hardiness zones, hydric, mesic, microclimate, xeric

SUMmARY. Botanical gardens continually seek new ways to improve their education programs and increase their audiences. In the case of most university gardens, the larger academic community presents many opportunities. H owever, what does a university garden do when separated by several hours travel from the campus served? $G$ arvan Woodland $G$ ardens and the U niversity of Arkansas (U A) have developed several ways to address this challenge. A summer school session and E Iderhostel program work together to benefit both partners in this alliance. This article discusses these efforts according to their structure, costs, and educational benefits.

M

ost gardens affiliated with colleges and universities are located near the main campus or are on an auxiliary campus. H owever, a few, such as Garvan Woodland Gardens, are quite remote from the academic communities they serve. This 200acre (81-ha), forested site owned by the U niversity of Arkansas Foundation, occupies two peninsulas in a 7,200-acre (2,914-ha) lake near $\mathrm{H}$ ot Springs $\mathrm{N}$ ational Park. Located 175 miles (282 km) and over $3 \mathrm{~h}$ by car from the land grant campus in Fayetteville, the gardens are far removed from the typical college experience, both in distance and spirit. This long-distance relationship requires that the gardens use a creative approach to serve the university community and its educational mission.

As with most institutions of higher learning, the U niversity of Arkansas has a 3-fold mission: academic services, research, and community service. Although still a developing garden with limited resources, Garvan Woodland Gardens uses several avenues to fulfill these goals and serve the university's various constituencies. While on-site research is not currently occurring at the garden, educational and public outreach objectives are served in several ways. This article discusses two of the most successful efforts to date: summer school and Elderhostel programs.

\footnotetext{
The cost of publishing this paper was defrayed in part by the payment of page charges. U nder postal regulation, this paper therefore must be hereby marked advertisement solely to indicate this fact.

${ }^{1}$ D irector, Garvan Woodland Gardens.
} 


\section{Summer school program}

In the most ambitious attempt at educational outreach, a summer school program offers garden access for students from the D epartment of $L$ andscape Architecture. This program has been in place for 4 years. Twelve to eighteen studentsstudy at the gardens for 5 weeks, spending mornings in an advanced plant materials class and afternoons in the second half of a two part planting design curriculum. The Arkansas School for $M$ athematics and Sciences, a statewide magnet high school, provides housing and studio space. The author serves as a plant materials instructor and J ohn C rone, professor of landscapearchitectureand former department head, teaches design and servesastheon-sitecoordinator of the program.

During the summer school session, instructorstake advantage of several opportunities presented by an offcampus teaching venue. The most notable are a significant change in climate, a broad range of native habitats available for study, large collections of endemic and nonnative plant materials for comparison, and use of the knowledge gained at the garden during design studies. These factors build on one another, producing exciting possibilities for teaching.

O needucational advantage of the remote location is a notable change in climate. Students receive most of their instruction at F ayetteville (U SD A Plant $\mathrm{H}$ ardiness Zone $6 \mathrm{~b}$, see Brickell (1989)). Garvan Woodland Gardens enjoys a milder Zone 8a microclimate, created by proximity to L akeH amilton. In addition, one enters Zone $7 \mathrm{~b}$ by traveling from the gardens just a few miles in any direction. These varied instructional settings represent all the hardinesszones that occur in the $\mathrm{M}$ idSouth, offering teaching opportunities normally enjoyed only by academic programs near major mountain ranges, coastlines, or other significant geographic features.

Students receive at least one plant materialscoursein F ayetteville'scolder climate before enrolling in the summer program. This experience provides valuable working knowledge of ornamental plants commonly used in the upper South. When students enter the second course at $\mathrm{H}$ ot Springs, they learn by building on previous educational experiences.
$U$ sing the principles of comparison and contrast, students greatly expand their understanding of the natural world and of cultivated plant materials. I n some instances those comparisons relate to cultural requirements. Asexamples, studentscomparekurume azaleas ( $R$ hododendron obtusum Planchon; Zones 6-8) with southern indicaazaleas( $R$ hododendr on indicum Planchon; Zones 7b-9), and franklin tree (Franklinia alatamaha $\mathrm{H}$. $M$ arshall; Zones 6-9) with cultivars of japanese camellia (Camellia japonica L.; Zones 7b-9). At other times, discussion centers on how to make use of locally adapted plants to achieve design effects normally associated with living materials from other climates. O ne plant pair illustrating this point for large conical evergreens is norway spruce (Picea abi esK arsten; Z one 3-8) contrasted with deodar cedar ( $C$ edrus deodara G. Don; Zone 7-9) (U SD A Plant $\mathrm{H}$ ardiness $Z$ one references from Brickell (1989)). As at least one member of each of these pairs will not grow well in both climates, these comparisons would be difficult if either location were the only teaching venue.

The summer school session also exploitsopportunities to teach by exploring native habitats. The Gardens contain several natural areas that have suffered only minimal disturbance. In contrast, most instruction

Fayetteville takes place within a rapidly developing suburban setting where truly undisturbed sites are rarely available for daily instructional use. Comparing unmanaged, wild areas with environments in which studentshave previously studied clearly illustrates issues designers face in their professional careers.

Early summer school class sessions expose students to a variety of these native environments. Participants in the 1997 session (Fig. 1) are shown observing identifying characteristicsof mockernut hickory (Carya tomentosa N uttall) along one of two large ridges that transverse the gardens.

Studentsexplorehydricareasfilled with sweet gum (Liquidambar styraciflua L.), willow oak (Quercus phellos L.), alder (A Inus rugosa K. Sprengel), baldcypress (Taxodium distichum L. Richard), virginia-willow (I tea virginica L.), and jewelweed (I mpatienscapensisM eerburgh). They visit mesic plateausand north slopesclothed in white oak (Quercusalba L.), southern red oak (Quercus falcata $A$. M ichaux), hophornbeam (O strya virginiana C. Koch), huckleberry (Vaccinium elliotti i Chapman) and partridge berry ( $M$ itchella repens L.). Studies also include xeric zones on south facing slopes that offer post oak (Quercusstellata Wangenheim), blackjack oak (Quercus marilandica
Fig. 1. L andscape architecture students from the $U$ niversity of Arkansas study identifying character- istics of mockernut hickory during a summer school class at $\mathbf{G}$ arvan Woodland G ardens.

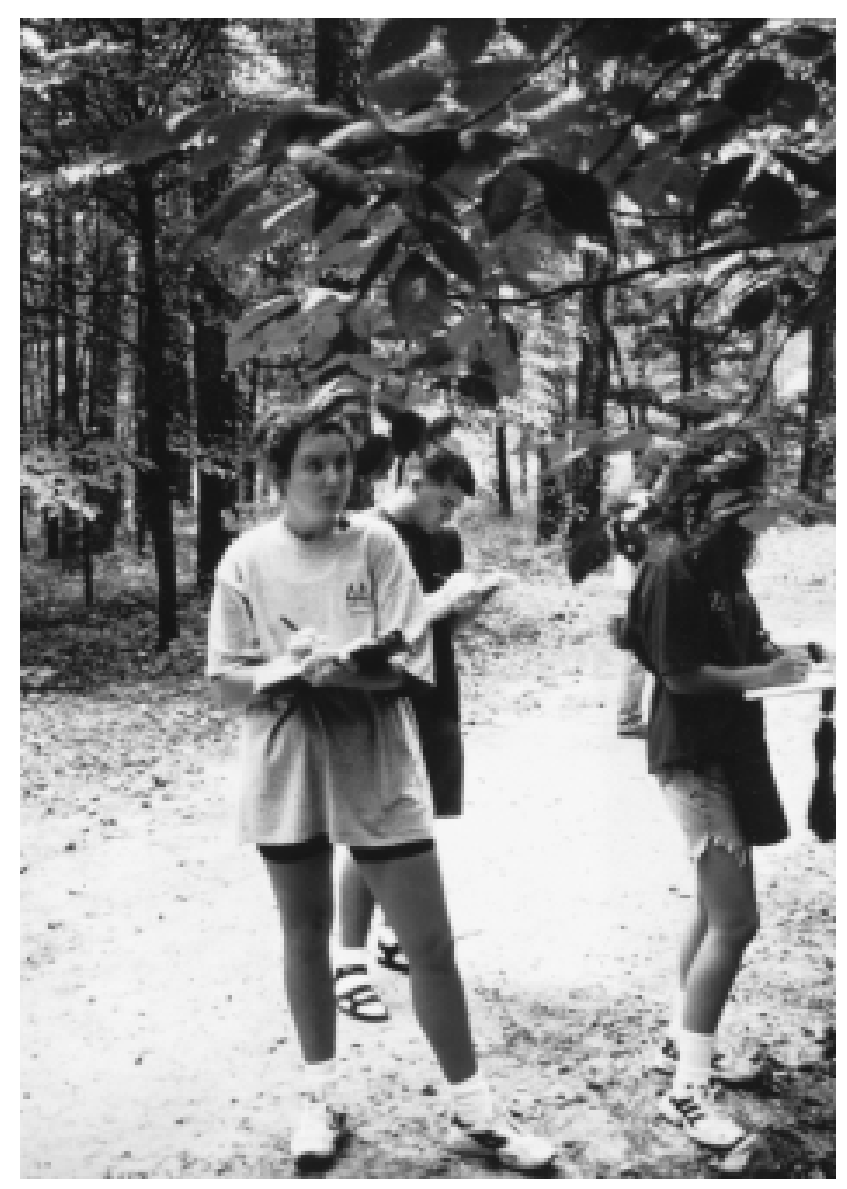


M uenchhausen), shortleaf pine(Pinus echinata P. M iller), hawthorn (C rataegusmarshallii Eggleston), fragrant sumac (R husaromatica Aiton), and crow poison ( $\mathrm{N}$ othoscordum bivalve Britton). As a result, students develop an understanding of therange of habitats possible within a small area, environmental conditions that make these plant communities different, and natural adaptations of the plants that occur there.

After exposure to these sites, students study nonnative plants within the garden's collections. The curriculum challenges them to decide, based on cultural requirements, which of the native plants studied earlier are most similar to these introduced speciesand what local environments most likely resemble each nonnative plant's natural range. Students begin building knowledge-based plant palettes well adapted to each microclimatethat they have previously learned to identify using indigenous indicator species.

To reinforce thislearning, several locations throughout the garden serve assites for design projectsin afternoon studios. Studentsbegin to connect the natural habitats of sites they design with both native and nonnative plant materialsthat areappropriate for those conditions. This allows greater perspective on their studies in plant identification and design courses.

\section{Elderhostel program}

Comparativestudies of plantsand their environmentspreparegarden staff well for the U niversity's Elderhostel program. A cooperative effort between the $U A$ D ivision of Continuing $E d u-$ cation and Elderhostel, I nc., this public outreach program enjoysgreat public response. Spring and fall sessions at the gardens teach participants about botanical gardens, garden design, and culture of ornamental plants. The students come from all over the U.S. and enjoy seeing familiar plants from their homes appear in the different guises of Arkansas' locally adapted species. For example, in 1998, visitorsfrom southern $\mathrm{N}$ ew England compared the 3inch $(7.6-\mathrm{cm})$ blossoms of southern indica azalea 'D uc de Rohan' with types of azaleas they grow in their home garden (Fig 2).

Participants often comment that plants seen at the gardensalso occur in the upper M idwest, the Gulf C oast, or other distant regions. This leads to discussions on why some plants occur over such wide native ranges while others grow only in geographically restricted areas. D iscussions arise on the nature of cold and heat tolerance and the mechanisms plants employ to copewith natural stresses. Thebreadth of personal experience represented by a group of 40 individuals, over the age of 50 and residing in many states, makes Elderhostel sessions rewarding for both students and instructors.

Elderhostel was the first educational activity begun at the gardens and has been in place for 8 years. As a less costly endeavor, it served as an important training ground, preparing staff for summer school sessions by defining some ways the gardens could establish an educational program. With each new session, the staff gains expanded knowledge of plants (or regionally-adapted taxa) that thrive in various parts of the country and in specific environments. This provides practical information used in planning and executing thecurriculum elements outlined above.

\section{Conclusions}

Both programs havebeen in place long enough to begin drawing some basic conclusions about their costsand benefits. Summer school is the most ambitious of the two programs and requires the most resources. The primary concernswith this program areas follows:

- Extra expense to the students. Although efforts are made to keep costsunder control, studentshave to pay living expenses at a time when they might live at home. A secondary impact is that working students lose 5 weeks of summer income.

- Extra administrative costs are associated with an off-campus educational program. Theprimarydemands have been extra time spent by the $C$ hair of the $D$ epartment of L andscape Architecture (also the gardens' executive director) and her staff arranging contracts with the Arkansas School for M athematics and Sciences for use of housing and studio facilities. These costs are declining as the program becomes established.

- Extra garden staff time. The plant materials class occupies 4 to $6 \mathrm{~h}$ a day of the director's time while summer school isin session. There is also a 1 to 2 week preparation period that requires an average of $2 \mathrm{~h}$ each day. In addition, the garden superintendent and a crew of two hourly workersspend about a day to set up and then another day to break down thestudio facility each year.

H owever, we feel that the following benefits justify the expenses:

- Extended class periods, typical of

Fig. 2. New England residents admire southern indica azalea ' $D$ uc de R ohan' while participating in an off-campus U niversity of Arkansas Elderhostel program in $\mathrm{H}$ ot Springs National Park.

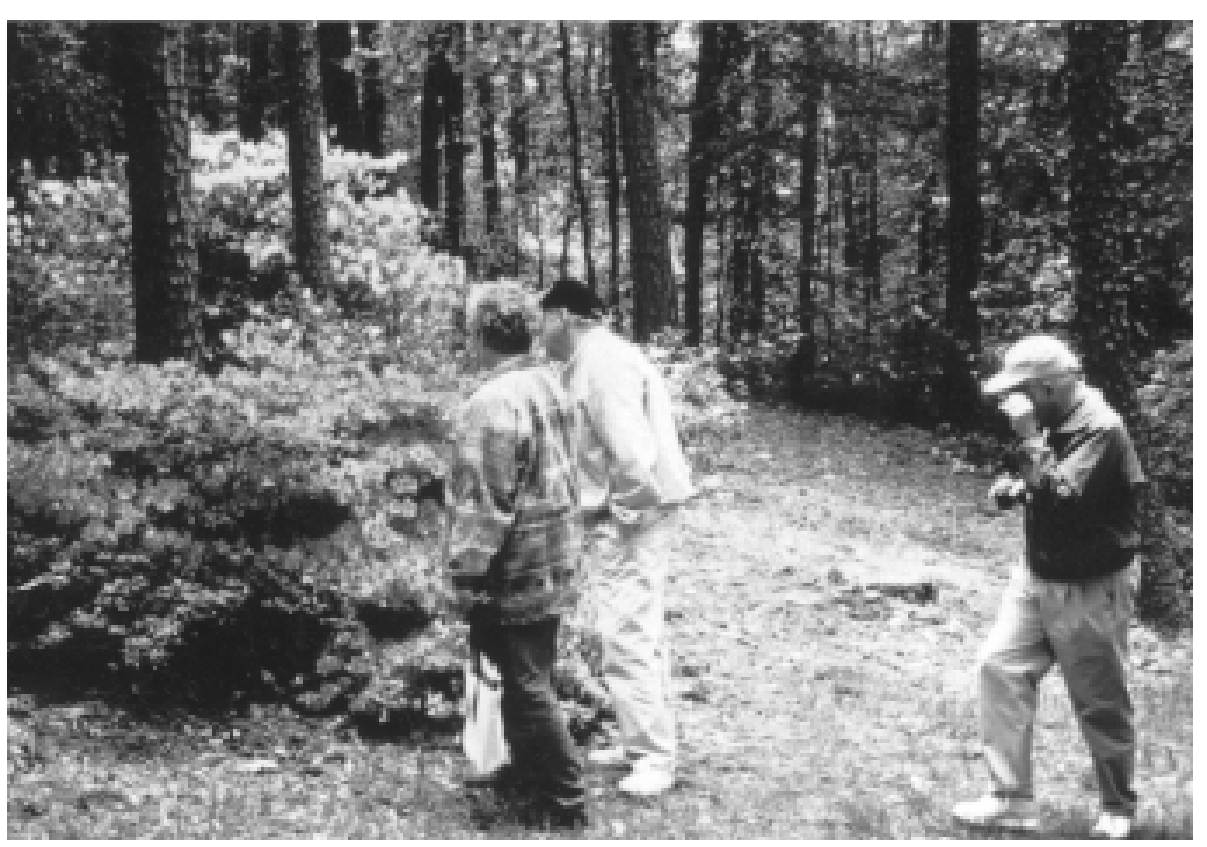


summer sessions, allow greater possibilities for in-depth study of a particular habitat in one visit. Exercises that would normally occupy most of a week' slecture time during regular semester sessions become feasible. This summer schedule allows a degree of continuity that is difficult to achieve under a typical college teaching regime.

- Access to the botanical garden collections is a tremendous teaching asset. A wide variety of species is on hand, allowing study of several members of a genus or family at one time. This creates many opportunities for learning plant community composition, plant identification characteristics, cultural requirements, design qualities, and uses.

- There are other intangible benefits that accrue from being in a new learning environment. Students appear more inquisitive than in standard classroom settings. A more casual approach to teaching encourages creativity and self-expression. Perhaps most importantly, opportunities for students to observe so many plants growing together offers inspiration to try new combinations in studio work during the summer session.

The administrative and staff concerns are similar for Elderhostel programs, but total costs are far less as each program lasts only $3 \mathrm{~d}$.
These programs provide interesting and worth while avenues by which a small university garden can serve the needs of both the academic community and of the general public. While the example of Garvan Woodland Gardens doesnot fit the profile of the average university garden, in many ways our institution is similar to smaller public gardens throughout the U.S. Working with educational institutions in distant parts of our state has offered us opportunities to expand our programs and reach new audiences. N onacademic botanical gardens and colleges without botanical gardensmay be ableto build on this model to create new educational outreach programs with other institutions. An example of such a program might be a distance learning program between a small urban college in need of natural areas for environmental curricula and a rural botanical garden which would like to expand its educational offerings.

$O$ vercoming the challenges of a longdistance relationship allows Garvan Woodland $\mathrm{G}$ ardens to continually explore new and exciting ways to use a wonderful and resource-rich facility. With thought and effort, other gardens could do the same.

\section{Literature cited}

Brickell, C. (ed.). 1989 The American H orticultural Society encyclopedia of garden plants. $M$ acmillan, $N$ ew York. 